\title{
Application of Character Education for Children with Special Needs in Special Schools of Perwari Padang
}

\author{
Firunika Intan Cahyani ${ }^{1}$, Eko Purnomo ${ }^{2}$, Eddy Marheni ${ }^{3}$ \\ 1Universitas Negeri Padang, Padang- Indonesia, \intanfirunika13@gmail.com \\ 2Universitas Negeri Padang, Padang- Indonesia, \ekopurnomo@fik.unp.ac.id \\ 3Universitas Negeri Padang, Padang- Indonesia, \eddymarheni@fik.unp.ac.id
}

\begin{abstract}
Children with special needs have problems with low social character and personal character. The purpose of this study is to find out the implementation of character education in children with special needs. This research is a qualitative research,This research was conducted on August 2 to September 29, 2018 at Special Schools of Perwari Padang, West Sumatra. The informants in this study were teachers who taught at the extraordinary Perwari Padang school which amounted to 5 people, with the object of research totaling 64 students special needs. Data collection methods use observation, documentation, interviews. The findings of the researcher indicate several behavioral problems which indicate that there is no personal character or social character in children with special needs (especially for mentally retarded children). The results of the study show the importance of applying the values of character education to children with special needs for the realization of a better national character.
\end{abstract}

Keywords:Exceptional schools, character, character education

\section{Introduction}

Education is an orderly system and carries a broad enough mission that is everything related to physical development, health, skills, thoughts, feelings, willingness, social issues to the belief or faith (Lilis, Rosita. 2018).Character becomes a necessity because education does not only make students smarter,also have manners and manners, so that its existence as a member of society becomes meaningful for both himself and others (Sri, Judiani. 2010).

The term character comes from the Greek "charassein" which means to carve.Forming characters is like carving a gemstone or a hard iron surface.Then further develops the notion of character which is interpreted as a special sign or pattern of behavior (Bohlin, Farmer, \& Ryan, 2001).Whereas according to Philips (2008) character is a collection of values that lead to a system, which underlies the thoughts, attitudes, and behaviors displayed. In can be concluded that the character is a true self-portrait of a person, where the self-portrait describes a person's behaviour whether good or bad. 
The notion of character education is education to form patterns of character or character from an early age,so that the good character is embedded and rooted in the child's soul.Character education is education that is not only oriented to cognitive aspects,but more oriented to the process of fostering the potential that is in the child,developed through the habituation of good qualities in the form of teaching good character values.Lickona (1991) states that character education is a deliberate effort to help someone so that he can understand,pay attention to, and carry out core ethical values.In character education,each individual is trained to be able to maintain good character in himself so that the character will be strongly attached to training through education so that good morals will be formed (Nela Rofisian. 2018).

The term impairment as stated by Frieda Mangunsong (2009: 5), usually more associated with medical or organic conditions,presence of disease or damage to a tissue.Children with special needs are the names for those who experience a different self from children in general.Various terms for these special need children include exceptional (different from people in general),impairment (damaged or deformed or sick, more on medical meaning),handicap (can't access the environment), and disability (no or lack of function) (Safrudin Aziz. 2014).Along with obtaining the same rights between normal children and children with special needs, then education in any form must be provided for all of them. One of the education programs that must be provided for children with special needs is character education.

An extraordinary school is one of the educational institutions with the aim to fulfill national education goals as well as to explore the abilities of students with special needs optimally (Fatah and Yusuf 2015).The application of character education in special schools is not much different from that applied in public schools. The difference lies in the presence of students with special needs in the class and the way the teacher instills character values in all students. The implementation of character education in class emphasizes caring, cooperation,respect differences, mutual respect and empathy (Nela Rofisian. 2018).

In providing education services,educational institutions may no longer see the background of their students in terms of their academic intellectual abilities,physical weakness, as well as mentality and emotions.By uniting into the same classroom, will give understanding to students that in life there will be many differences. These differences should not be used as obstacles, but rather a reality that must be faced and respected.That is the reality of life that must be experienced together.This plural condition and learning situation can be a very effective character education medium for all students.A sense of empathy, sympathy, caring, and self-awareness will appear in the learning settings of this model (Nela Rofisian. 2018).By fulfilling the need for education of children with special needs are expected to take care of themselves and can release dependence on others. The maximum number of children with special needs in educational institutions means that some of their needs are met.It is hoped that through education they will be able to expand their horizons.So as to be able to think creatively, innovatively and productively (Nandiyah Abdullah. 2013).

Indications of character problems in children with special needs are the emergence of less independent behavior,less able to self-regulate,emotional and less responsible, especially for mentally retarded children and dwon syndrome.Besides that, fighting behavior,speak impolite,less caring about other people, deaf children sometimes like to be picky friends and like to oppose orders is an indication of character problems in children with special needs.In accordance with the opinion of Sri Judiani (2010), which consists of Religious values, Honesty, Tolerance, Discipline, Creative, Independent, tolerance, Curiosity, Appreciate Achievement, Friendly / Communicative, democracy, patriotism, as well as nationality, Reading Love, Caring for the Environment, Social Care, Responsibility Answer, and Love Peace.The teacher only applies responsibilities, empathy, communication, and cooperation. Religious, Honesty, Tolerance, Discipline, Creative, Independent, Tolerance, Curiosity, Appreciate Achievement, Friendly / Communicative, Love to Read, Care for the 
Environment, Social Care, Responsibility, and Peaceful Love in the teaching and learning process in the classroom.

\section{Methodology}

The type of research used in this study is qualitative research, with data collection methods using interviews and focus group discussions (FGD). This research was conducted on 2 August - 29 September 2018 at Padang Perwari Special School, West Sumatra. In addition, the interview and documentation process is also carried out when collecting data. The informant for this study was chosen for several reasons. In order to gather information that creates a greater understanding of how student experience having a sport psychology consultant, data was collected from individuals who directly experienced the phenomena of interest (Patton, 2002). The informants used were taken by necessity consisting of 5 informants who were teachers who taught at the extraordinary Padang Perwari school. Objects in this study amounted to 64 students who are children with special needs in the extraordinary school Perwari Padang. The data collection techniques and tools use the observation method, interviews and documentation. Data analysis techniques in this study are more of a description of the observations, interviews and documentation. The data that has been obtained will be analyzed qualitatively and described in descriptive form (Patton, 2001: 103). Data analysis is "The process of arranging data sequences, organizing them into a pattern, category and basic description". The data analysis technique used in this study is to use steps as stated by Burhan Bungin (2003: 70), namely as follows:

1. Data collection

2. Data reduction

3. Display data

4. Conclution drawing and verification

Table 1 Research Instrument

\begin{tabular}{cll}
\hline No & Value & Description \\
\hline 1 & Religious & $\begin{array}{l}\text { Attitudes and behaviors that are obedient in carrying out the } \\
\text { teachings of the religion he adheres to, tolerant of the } \\
\text { implementation of other religious services, and live in harmony } \\
\text { with other religious followers. }\end{array}$ \\
\hline 2 & Honest & $\begin{array}{l}\text { Behavior that is based on the effort to make himself as a person } \\
\text { who can always be trusted in words, actions, and work. }\end{array}$ \\
\hline 3 & Tolerance & $\begin{array}{l}\text { Attitudes and actions that respect differences in religion, ethnicity, } \\
\text { ethnicity, opinions, attitudes and actions of others who are } \\
\text { different from themselves. }\end{array}$ \\
\hline 5 & Discipline & $\begin{array}{l}\text { Actions that show orderly behavior and comply with various rules } \\
\text { and regulations. }\end{array}$ \\
\hline 6 & Hard work & $\begin{array}{l}\text { Behavior that shows genuine effort in overcoming various } \\
\text { obstacles to learning and assignments, as well as completing the } \\
\text { task as well as possible. }\end{array}$ \\
\hline 7 & Creative & $\begin{array}{l}\text { Think and do something to produce new ways or results from } \\
\text { something that you already have. }\end{array}$ \\
\hline 8 & Mandiri & $\begin{array}{l}\text { Attitudes and behaviors that are not easily dependent on others in } \\
\text { completing tasks. }\end{array}$ \\
\hline
\end{tabular}




\begin{tabular}{|c|c|c|}
\hline 9 & Curiosity & $\begin{array}{l}\text { Attitudes and actions that always strive to find out more deeply } \\
\text { and broadly from the things they learn, see, and hear. }\end{array}$ \\
\hline 10 & $\begin{array}{c}\text { Spirit of } \\
\text { nationality }\end{array}$ & $\begin{array}{l}\text { The way of thinking, acting and being insightful that places the } \\
\text { interests of the nation and state above the self and group interests. }\end{array}$ \\
\hline 11 & $\begin{array}{l}\text { Love the } \\
\text { Fatherland }\end{array}$ & $\begin{array}{l}\text { How to think, behave and act that shows loyalty, care, and high } \\
\text { appreciation for the language, physical environment, social, } \\
\text { cultural, economic and political nation. }\end{array}$ \\
\hline 12 & $\begin{array}{c}\text { Appreciate } \\
\text { Achievements }\end{array}$ & $\begin{array}{l}\text { Attitudes and actions that encourage him to produce something } \\
\text { useful for the community, and recognize, and respect the success } \\
\text { of others. }\end{array}$ \\
\hline 13 & $\begin{array}{c}\text { Friendly } \\
\text { (Communicative) }\end{array}$ & $\begin{array}{l}\text { Actions that show pleasure in talking, associating, and working } \\
\text { with others. }\end{array}$ \\
\hline 14 & Love peace & $\begin{array}{l}\text { Attitudes, words and actions that cause others to feel happy and } \\
\text { safe for their presence. }\end{array}$ \\
\hline 15 & Like to read & $\begin{array}{l}\text { Habits provide time to read various readings that provide good for } \\
\text { him. }\end{array}$ \\
\hline 16 & $\begin{array}{l}\text { Environmental } \\
\text { care }\end{array}$ & $\begin{array}{l}\text { the surrounding natural environment and develop efforts to repair } \\
\text { the natural damage that has already occurred. }\end{array}$ \\
\hline 17 & Social care & $\begin{array}{l}\text { Attitudes and actions that always want to provide assistance to } \\
\text { other people and communities in need. }\end{array}$ \\
\hline 18 & Responsible & $\begin{array}{l}\text { Attitude and behavior of a person to carry out his duties and } \\
\text { obligations, which he should do, to himself, society, environment } \\
\text { (natural, social and cultural), the country and God Almighty. }\end{array}$ \\
\hline
\end{tabular}

Source (Sri Judiani. 2010)

From a total value and description of the value of character education researchers will only take religious values, honesty, tolerance, discipline, creative, independent, tolerance, curiosity, appreciating achievement, friendship / communicative, fond of reading, caring for the environment, social care, responsibility, and Love of Peace.This is because the values given by the teacher at the extraordinary school are Perwari Padang in every teaching and learning process.

\section{Results and Discussion}

The findings of the study indicate several behavioral problems which indicate that there is no personal character or social character in children with special needs (especially for mentally retarded children).For example, Indications of personal character problems in children with special need are the emergence of less independent behavior,less self-regulating, emotional and less responsible.Indications of social character problems are indicated by symptoms of fighting behavior,talking disrespectfully, not caring about others, waiting children sometimes like to be picky friends and like to oppose orders.Based on the findings, the characters that need to be developed in children with special need are compliance, self-regulation, self-help, self-control, responsibility, empathy, communication, and collaboration.

The findings of the implementation of character education at the special school of Perwari Padang can be seen in the value table and description of character education values below :

Table 2The Value Table and Description of Character Education

\begin{tabular}{lll}
\hline No & $\begin{array}{l}\text { Character } \\
\text { Education Values }\end{array}$ & Observation Findings / Results \\
\hline 1 & Religious & $\begin{array}{l}\text { Teachers at school extraordinary schools Perwari apply } \\
\text { religious values to children with special needs by } \\
\text { applying it to spiritual activities carried out on Friday } \\
\text { morning. The activities carried out in the form of Dhuha }\end{array}$ \\
\hline
\end{tabular}




\begin{tabular}{|c|c|c|}
\hline & & $\begin{array}{l}\text { prayer together, reading iqra and memorizing short } \\
\text { surahs }\end{array}$ \\
\hline 2 & Honesty & $\begin{array}{l}\text { Applying honest behavior to students can be seen when } \\
\text { students shop at the school canteen.This is based on the } \\
\text { results of interviews with teachers and food vendors in } \\
\text { the school canteen,students usually give their money } \\
\text { before taking food.Besides that the teacher also gives a } \\
\text { warning in the form of punishment for students who are } \\
\text { caught lying so that students have the fear to do so. }\end{array}$ \\
\hline 3 & Tolerance & $\begin{array}{l}\text { The tolerance values applied by the teachers at the } \\
\text { extraordinary Perwari Padang School,usually applied to } \\
\text { morning gymnastics activities on Saturday and scout } \\
\text { activities. This is done so that students can appreciate the } \\
\text { shortcomings of their friends.For example, with these } \\
\text { activities held for mentally retarded, deaf and } \\
\text { dwonesindrom children, they can gather to communicate } \\
\text { or play together without having to be picky friends. Thus, } \\
\text { it will increase mutual respect for children with special } \\
\text { needs. }\end{array}$ \\
\hline 4 & Discipline & $\begin{array}{l}\text { The value of discipline in children with special needs in } \\
\text { special schools Perwari Padang can be seen when the } \\
\text { lesson begins. When the school bell rang the children } \\
\text { immediately entered their classrooms.However, } \\
\text { specifically for mentally retarded children who are still in } \\
\text { a small class, the attitude of discipline still needs to be } \\
\text { improved.This is because children who are still } \\
\text { unfamiliar with obeying the rules at school.The effort } \\
\text { made by the teacher is to persuade the child to go to } \\
\text { class.For example, by being given their favorite food or } \\
\text { carrying them. }\end{array}$ \\
\hline 5 & Creative & $\begin{array}{l}\text { The application of creative values to children with } \\
\text { special needs can be seen in mulok subjects.In this lesson } \\
\text { children are nurtured to be able to make something.For } \\
\text { example, sewing, drawing, embroidery and making } \\
\text { crafts.Children are free to explore themselves to make a } \\
\text { work. }\end{array}$ \\
\hline 6 & be autonomous & $\begin{array}{l}\text { Independent attitudes generally have been recognized by } \\
\text { children with special needs,like you can urinate } \\
\text { yourself,mentally disabled children can wear shoes or fix } \\
\text { their own clothes.Besides that, it can also be seen during } \\
\text { ceremonies and morning exercises on Saturdays,children } \\
\text { in large classes are used to preparing their ranks without } \\
\text { orders from their teacher.Children are also taught to } \\
\text { clean up the class before the lesson begins. }\end{array}$ \\
\hline 7 & Curiosity & $\begin{array}{l}\text { When you will start the lesson first the teacher invites } \\
\text { students to pray together then continue with interesting } \\
\text { games where the games educate students to think } \\
\text { creatively and team collaboration,things done in the deaf } \\
\text { and disabled class.By holding games students will have } \\
\text { curiosity in learning at the same time so that the learning }\end{array}$ \\
\hline
\end{tabular}




\begin{tabular}{|c|c|c|}
\hline & & process is not boring. \\
\hline 8 & $\begin{array}{l}\text { Appreciate } \\
\text { Achievements }\end{array}$ & $\begin{array}{l}\text { In schools, it is extraordinary that Perwari teachers } \\
\text { implement self-development efforts in the subject of } \\
\text { skills,arts, scouts and sports activities. This is done so that } \\
\text { students directly explore themselves with guidance from } \\
\text { their teacher.Besides this self-development activities are } \\
\text { intended to generate achievement motivation for } \\
\text { students.Because students at the extraordinary School } \\
\text { Perwari have been able to perform well at the provincial } \\
\text { level in West Sumatra and at the national level.Most of } \\
\text { the children in the School are outstanding in the field of } \\
\text { sports and arts. }\end{array}$ \\
\hline 9 & $\begin{array}{l}\text { Friendly } \\
\text { (Communicative) }\end{array}$ & $\begin{array}{l}\text { The efforts made by the teacher at the extraordinary } \\
\text { School Perwari Padang,actually there is no } \\
\text { language/communication pattern that is typical for } \\
\text { children with special needs.Because of the variety of } \\
\text { characters that students have usually the teacher first } \\
\text { understands each of his students before placing himself } \\
\text { to give lessons. When I will start the lesson first the } \\
\text { teacher invites the students to pray together then } \\
\text { proceed with interesting games where the games educate } \\
\text { students to think creatively and teamwork,things done in } \\
\text { the deaf and disabled class.As for mentally disabled } \\
\text { children, communication is done with interesting things } \\
\text { such as inviting singing but not with long lyrics. }\end{array}$ \\
\hline 10 & Like to read & $\begin{array}{l}\text { The effort to implement the love of reading by the } \\
\text { teacher in the School is extraordinary in Perwari Padang } \\
\text { by inviting students to the library and holding reading } \\
\text { together.Children are given colorful picture books so that } \\
\text { children are interested in reading them.Besides that, the } \\
\text { making of mading by the teacher is also an effort of } \\
\text { students to love reading. }\end{array}$ \\
\hline 11 & Environmental care & $\begin{array}{l}\text { Environmental care can be seen when students will go to } \\
\text { class or go home from school.Students are taught to } \\
\text { throw garbage in its place.In addition to cleaning the } \\
\text { school environment as well as efforts made by the } \\
\text { teacher will care about environmental cleanliness. }\end{array}$ \\
\hline 12 & Social care & $\begin{array}{l}\text { Social care for students is also taught to care for others } \\
\text { such as caring for others by handing out funds to } \\
\text { earthquake victims hammer recently. Children in } \\
\text { extraordinary schools Perwari Padang are taught to } \\
\text { empathize with others,even though they have } \\
\text { weaknesses in themselves.This is done so that the } \\
\text { children in the extraordinary school of Perwari have a } \\
\text { sense of gratitude even though they are not perfect but } \\
\text { are still in good condition.The sense of care created by } \\
\text { the teachers of the Perwari extraordinary school is done } \\
\text { with interesting communication so that children with } \\
\text { special needs for mentally retarded children can focus on } \\
\text { their teachers.This good and interesting communication }\end{array}$ \\
\hline
\end{tabular}


is the main thing that extraordinary School Teachers

have in applying character education values in schools

13 Responsible The value of responsibility for students of extraordinary schools Perwari Padang can be seen when the teacher gives responsibility for tidying up the class after the lesson is over.In addition to large class students can be seen as having responsibility in preparing equipment for morning gymnastics on Saturday.His older children also guide their younger siblings to carry out the activities carried out by the school.For example culture, scouting activities, sports etc.

14 Love peace Peaceful love here can be seen when students immediately apologize when guilty to a friend.Based on observations made by researchers, usually students hug his friend after they have finished fighting or hitting each other (this is usually done by the children of dwonsyndrome and mental retardation).Advising, accompanying, giving examples, and creating a comfortable atmosphere is one of the efforts that teachers do to apply peace to students.

In addition to the findings above, the researcher also obtained information from several students through the interview process where several students with special needs said that they got character education from their parents at home,they have applied the values of independence,spirituality, honesty, responsibility, social care and others.The children claimed that they would be more comfortable making friends with friends who could accept their situation (accepting their shortcomings) than friends who hurt or ridiculed him. When they get mistreated from other people they are better off and away,this is done so that this will not happen to them again.This sense of trauma is what makes the confidence of children with special needs have low self-confidence caused by ill-treatment of the environment in which they are located.For that love and caring should be given to these children with special needs, this is done so that children with special needs have confidence and optimism in living their lives.

The sense of care created by the teachers of the Perwari extraordinary school is done with interesting communication so that children with special needs for mentally retarded children can focus on their teachers.This good and interesting communication is the main thing that the extraordinary school teacher Perwari has in applying the values of character education in school.This is in accordance with the opinion of Anik Ghufron (2010),Integrating national character values into learning activities means integrating,enter and apply values that are believed to be good and true in order to form,develop, and foster the nature or personality of students according to national identity when learning activities take place.

The character of honesty and compliance is a form of social influence,the child carries out certain behaviors by not heeding his own judgment because of getting demands from those who have authority or authority.Compliance can occur due to authority, rewards, and punishments and parental expectations.Conversely, children's disobedience and honesty towards certain rules can occur due to several things, among others because of the low skills and disability of his body (Ducharme \& DiAdamo, 2005).The disobedience and dishonesty of children will harm themselves and others.Children who are often disobedient and dishonest are often not socially accepted or intimidated because they are considered to damage the social order and moral behavior (Buhs \&Ladd, 2001).Children with special needs have limited mental abilities and physical abilities that affect their social abilities.Children experience difficulties in accepting social relationships, feeling eliminated and experiencing dissatisfaction in their social life (Kumar Singh \& Akhtar, 2009). 
In this regard, communication and collaboration skills also need to be developed for children with special needs.Children with special needs have some limitations in their social life,including communicating and interacting. Therefore,Adequate support from those around him can improve the quality of life (AAMR, 2002).The efforts made by the teacher at the extraordinary School Perwari Padang,actually there is no language pattern that is typical for children with special needs.Because of the variety of characters that students have usually the teacher first understands each of his students before placing himself to give lessons. When I will start the lesson first the teacher invites the students to pray together then proceed with interesting games where the games educate students to think creatively and teamwork,things done in the deaf and disabled class.As for mentally retarded children,communication is done with interesting things such as inviting singing but not with long lyrics.This is in accordance with Tri and Dyah (2013), that mentally retarded children have a slow understanding of communication, especially in long and meaningful complex sentences.

Children who have close relationships with others will foster a pleasant atmosphere.This atmosphere can stimulate children's social character, especially helping each other and protecting each other from social pressure. This condition will also stimulate four because of its limitations, most children with special needs also have problems in empathy.Children are able to show good perseverance and empathy as long as they get service or treatment and a conducive environment (Tri and Dyah. 2015).Based on the research,then actually the social character of the child can be developed if the children with special needs get proper care from their parents, teachers and the people around them.

Regarding his personal life,self-regulation, self-help, and self-control capabilities need to be developed.The findings of this study indicate that children are less able to regulate themselves,low self-confidence, tends to behave arbitrarily,cannot follow a routine regulation or activity.Selfregulation, self-help and self-control are abilities related to Activity of Daily Living (ADL) or daily activity activities or known as self-development.Self-development is a personal activity but has an impact and is related to social relations,for example related to tasks that must be carried out by themselves without the help of others if conditions permit.

The method often used by teachers at the special school Perwari Padangto improve social character and personal character of children with special needs is by giving advice, accompany,give an example,and create a comfortable atmosphere.This method is called the induction method (Tri and Dyah. 2015).The form of treatment used in the induction method is to provide positive examples by discussing children's behavior with their families and with their children and giving reasoning without being accompanied by punishment. The method of induction has better results in children of primary school age (Tri and Dyah. 2015).In addition, one of the implications of character education is to create an atmosphere / atmosphere that is fun for children (Australian Commonwealth, 2005).Through a pleasant climate there will be an internalization of moral values of mutual love,respect for older people, help each other, and communicate.Activities that can be done,namely involving children in social activities both at school and at home.Children will feel comfortable because they are not underestimated by their environment,children also feel comfortable because they are given the opportunity to participate despite their limitations.Scolding a child for doing bad deeds is also used.The act of scolding children is a form of violence against children.Factors that cause violence against children include children with disabilities,mental retardation, behavioral disorders, autism, and family poverty.This condition causes stress in children with special needs.Research by Tri and Dyah (2015),troubled children show that being accustomed to a bad environment (or in the sense of watching violence such as fighting etc.) hitting or screaming can cause a child to be depressed and behave negatively (http://terapiemosi.com).

The act of giving physical punishment to children,instead giving a message that the child may carry out such behavior, the child will try to respond to that behavior to his parents.That individuals become aggressive as a result of the results of the demonstration of aggression carried out by their parents and those around them (Koeswara. 1988). 


\section{Conclusions and Recommendations}

Children with special needs have problems with the low social character and personal character.This is indicated by a number of behavioral problems that are less independent,lack of responsibility, lack of self-control, lack of self-control, fighting, speaking disrespectfully, not caring about others and being opposed.The efforts made by the teacher in applying the values of character education is with extracurricular activities (talent development), such as religious activities on Fridays, scouts, arts, drawing, sewing and sports activities.Good communication between teachers with special needs children is also an important aspect in applying character education values for children with special needs. With the application of character education to children with special needs it is hoped that children will have good personalities and character in living their daily lives both within the school, family and community

\section{References}

Abdullah, Nandiyah. (2013). Mengenal anak berkebutuhan khusus. Universita Widhaya Darma Klaten Magistra No. 86 Th. XXV Desember 2013 ISSN 0215-9511

Al Irsyadi, Fatah Yasin dan Nugroho, Yusuf Sulistyo. (2015). Game edukasi pengenalan anggota tubuh dan pengenalan angka untuk anak berkebutuhan khusus (abk) tunagrahita berbasis kinect. Universitas Muhammadiyah Surakarta Prosiding SNATIF Ke -2 ISBN: 978-602-1180-21-1

American Association on Mental Retardation (AAMR) (2002). Mental retardation-definition, Classification and systems of supports, $10^{\text {th }}$. Washington, D.C.: AAMR.

Aziz, Safrudin. (2014). Pendidikan seks bagi anak berkebutuhan khusus.. Jurnal Kependidikan, Vol. II No. 2 November 2014

Bungin, Burhan. (2003). Analisis data penelitian kualitatif. Jakarta: PT Raja Grafindo Persada.

Bohlin, E. Karen., Deborah Farmer, \& Kevin Ryan, (2001). Building character in school resource guide. San Fransisco: Jossey Bass.

Commonwealth of Australia, (2005). Values education forum: Engaging your school community Australia: Departement of Education, Science and Training

Dampak Sering Memarahi Anak, dalam http://terapiemosi.com

Ducharme, J., \& DiAdamo, C. (2005). An errorless approach to management of child noncompliance in a special education setting. Research Brief. School Psychology Review, 34(1), 107-115.

Ghufron, Anik. (2010). Integrasi Nilai-Nilai Karakter Bangsa Pada Kegiatan Pembelajaran. Universitas Negeri Yogyakarta Cakrawala Pendidikan, Mei 2010, Th. XXIX, Edisi Khusus Dies Natalis UNY

Judiani, Sri. (2010). Implementasi Pendidikan Karakter di Sekolah Dasar Melalui Penguatan Pelaksanaan Kurikulum. Setditjen Manajemen Pendidikan Dasar dan Menengah, Kemendiknas Jurnal Pendidikan dan Kebudayaan, Vol. 16, Edisi Khusus III, Oktober 2010

Koeswara, E. (1988). Agresi manusia. Bandung.: PT. Eresco.

Kumar, I., Singh.A.R. \& Akthar.S. (2009). Social development of children with mental retardation. Industrial Psychiatry Journal.18 (1):56 - 59 
Lickona, Thomas. (1991). Educating for Character: How Our School Can Teach Respect and Responsibility. New York: Bantam Books.

Mangunsong, Frieda. (2009). Psikologi dan Pendidikan Anak Berkebutuhan Khusus Jilid 1. Jakarta: LP3S3 UI.

Na'imah, Tri dan Septianingsih, Dyah Siti. (2015). Pendidikan Karakter Untuk Anak Berkebutuhan Khusus (Studi Relasi Gender Pada Keluarga Yang Memiliki Anak Tuna Grahita Ringan). Universitas Muhammadiyah Purwokerto Prosiding SNaPP2015 Kesehatan pISSN 2477-2364 I eISSN 24772356

Patton, M. Q. (2002). Qualitative Researchand Evaluation Methods (3rded.). Thousand Oaks, CA: Sage Publications, Inc.

Phillips, Simon. (2008). Refleksi Karakter Bangsa. Jakarta:

Rofisian, Nela. (2018). Konsep pendidikan karakter pada anak berkebutuhan khusus. Universitas Widya Dharma Klaten. Prosiding Konferensi Ilmiah Dasar 2018 Volume 1 | 19 - 25 ISSN: 2621-8097

Rosita, Lilis. (2018). Peran Pendidikan Berbasis Karakter Dalam Pencapaian Tujuan Pembelajaran Di Sekolah. Bandung: Universitas Wanita Internasional. Jurnal Ilmu Politik dan Komunikasi Volume VIII No. 